\title{
Asbestos induced diffuse pleural fibrosis: pathology and mineralogy
}

\author{
M STEPHENS, A R GIBBS, F D POOLEY, J C WAGNER \\ From the Department of Pathology, Llandough Hospital, Penarth; the Institute of Materials, University \\ College, Cardiff; and the Medical Research Council Exernal Staff Team on Occupational Lung Diseases, \\ Llandough Hospital, Penarth
}

ABSTRACT Lungs from seven cases of diffuse pleural fibrosis with known asbestos exposure were studied to determine the gross and microscopic pathological features and relate these to the analysed mineral fibre content of the lung. All seven individuals had had substantial exposure, ranging from two to 25 years, and chronic chest problems and at necropsy all cases met the criteria for compensatable disease. Macroscopically, all had extensive visceral pleural fibrosis and extensive areas of adhesions, and four also had discrete parietal pleural plaques. The histological features were similar in all the cases-most strikingly the basket weave pattern of the thickened pleura and a dense subpleural parenchymal interstitial fibrosis with fine honeycombing, extending up to $1 \mathrm{~cm}$ into the underlying lung. The similar histological appearances raise the possibility that diffuse pleural fibrosis and pleural plaques have a similar pathogenesis. Amphibole asbestos (crocidolite and amosite) counts were high in six of the seven cases and chrysotile counts in four; four cases had high mullite counts, but the importance of this is not known. It is concluded that diffuse pleural fibrosis is a specific asbestos associated entity, of uncertain pathogenesis, with mineral fibre counts falling between those found with plaques and those in minimal asbestosis.

\section{Introduction}

Diffuse pleural fibrosis is a well recognised component of asbestos induced parenchymal disease, ${ }^{1}$ but only more recently has it become accepted as a specific entity in its own right. ${ }^{2}$ Some clinicoradiological reports have appeared, but the underlying pathological changes remain poorly documented and no mineralogical data are at present available. In this paper we describe the gross and microscopic features of the condition and discuss the relationship with the analysed pulmonary mineral fibre content.

\section{Methods}

Lungs were examined from necropsies performed from 1979 to 1986 on seven cases of known asbestos exposure. They were drawn from about 1200 asbestos related necropsies. Clinical and occupational histories

Address for reprint requests: Dr A R Gibbs, Department of Pathology, Llandough Hospital, Penarth, S Glamorgan CF6 1XX. were obtained from hospital notes or from the Pneumoconiosis Medical Panel. Causes of death were obtained from death certificates.

\section{TISSUE PREPARATION}

Lungs were distended by formalin in the standard manner and examined macroscopically after fixation. Blocks of tissue were taken from the apex of the upper lobe, the apex of the lower lobe, and the base of the lower lobe. In addition, several blocks were taken from the visceral pleural surface. The centre of each of the parenchymal blocks was taken for histological examination and the remainder submitted for mineralogical analysis.

Paraffin sections were prepared and stained by haematoxylin and eosin; Martius scarlet blue was used for fibrous tissue, and elastic-Van Gieson's method for elastic and fibrous tissue. The degree of parenchymal fibrosis was graded from 0 to 4 by an established system for each histological slide and an average was obtained for each case. ${ }^{34}$

MINERAL FIBRE ANALYSIS

Both light microscopic and electron microscopic counts were undertaken. The light microscopic 
Table 1 Diffuse pleural fibrosis: clinical and occupational features

\begin{tabular}{|c|c|c|c|}
\hline Case No & $\operatorname{Age}(y)$ & Occupation & Clinical features \\
\hline 1 & 80 & $\begin{array}{l}\text { Pipe fitter ( } 25 \text { y asbestos } \\
\text { exposure) }\end{array}$ & $\begin{array}{l}\text { Severe dyspnoea and wheeze for } 10 \text { years; chronic obstructive airways disease; } \\
\text { coexistent restrictive ventilatory defect; smoker }(20 / \text { day for } 50 \mathrm{y})\end{array}$ \\
\hline 2 & 75 & Electrical welder & $\begin{array}{l}\text { Chronic chest disease with recurrent chest infections for several years; smoked } \\
\text { 20/day for several years }\end{array}$ \\
\hline 3 & 67 & $\begin{array}{l}\text { Engineer ( } 2 \text { y exposure cutting } \\
\text { asbestos sheets } 40 \text { y ago) }\end{array}$ & "Chronic chest disease" for 4 years \\
\hline 4 & 69 & $\begin{array}{l}\text { Maintenance fitter ( } 2 \text { y exposure } \\
20 \text { y ago) }\end{array}$ & Productive cough for several years; smoked 50/day for several years \\
\hline 5 & 58 & $\begin{array}{l}\text { Caravan maker - blue asbestos } \\
\text { (9 y exposure } 15 \text { y ago) }\end{array}$ & $\begin{array}{l}\text { Recurrent pleural effusions for } 2 \text { y; normal lung function test results } 7 \text { y before } \\
\text { death; smoked } 20 \text { /day for several years }\end{array}$ \\
\hline 6 & 68 & Munitions factory worker & $\begin{array}{l}\text { Recurrent bilateral pleural effusions for } 4 \mathrm{y} \text {; recurrent chest infections; } \\
\text { smoked } 20 \text { /day for several years }\end{array}$ \\
\hline 7 & 64 & Ex-boilermaker (heavy exposure) & $\begin{array}{l}\text { "Obstructive airways disease" for } 7 \text { y; bilateral pleural thickening noted } \\
\text { radiologically } 7 \text { y before death; smoked } 20 / \text { day for several years }\end{array}$ \\
\hline
\end{tabular}

counts were performed by the method of Ashcroft. ${ }^{5}$ Briefly, lung tissue was divided into two portions and weighed, one half being dried and reweighed and the other digested by immersion in sodium hydroxide. After centrifugation the supernatant was aspirated and the sediment resuspended in water. An aliquot was then transferred to a Fuchs-Rosenthal chamber and fibres were counted by phase contrast microscopy. The count was related to the dry weight of the lung tissue. Electron microscopic counts were per-

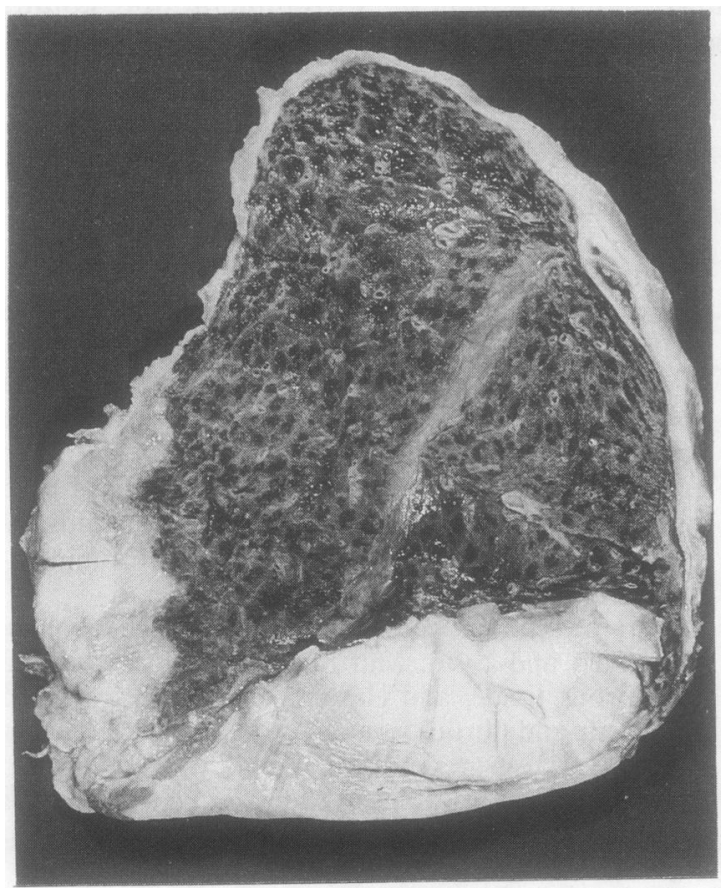

Fig 1 The lung from case 2, showing complete encasement by diffuse pleural thickening. The under surface is shown in the lower part of the figure. formed as a standard procedure. ${ }^{6}$ Tissue samples were dried at $80^{\circ} \mathrm{C}$, digested in sodium hydroxides washed, and ashed in an oxygen atmosphere. The final extract was suspended and filtered on to a nucles? apore filter. The filter preparation, laden with dust from a known weight of dried tissue, was coated wit carbon, the filter dissolved with chloroform, and the carbon film mounted on to a gold electron micr@ scope support grid. The electron microscopic prep年 rations were examined and all fibrous particles cous ted, the figures obtained being related to the origing dry weight of the lung tissue. Then 100-200 fibres were analysed by an energy dispersive $x$ ray analys technique. ${ }^{7}$

\section{Results}

CLINICAL AND OCCUPATIONAL FINDINGS

All cases were male and had had substantial exposuxe to various types of asbestos, ranging from two to 25 years (table 1). Clinically, all had had chronic cheist problems and in particular two had evidence of recuor rent unexplained pleural effusions. Diffuse pleurâ thickening was observed radiologically before death in cases 1,4 , and 7. Diagnoses of diffuse pleur fibrosis were obtained only after necropsy in cases 3,5 , and 6; plaques had been noted radiologically gi case 5 , but in none were the radiological changes of diffuse pleural fibrosis observed.

PATHOLOGY

Macroscopic findings

In all cases there was extensive visceral pleuri fibrosis, most noticeable at the bases but extending over the upper lobes (fig 1). This was bilateral and many areas greater than $5 \mathrm{~mm}$ in thickness. extended over more than half of each lung surfag and in two cases covered the whole lung. There were extensive areas of adhesion between the pleura and the chest wall, giving rise to difficulty in removing the 


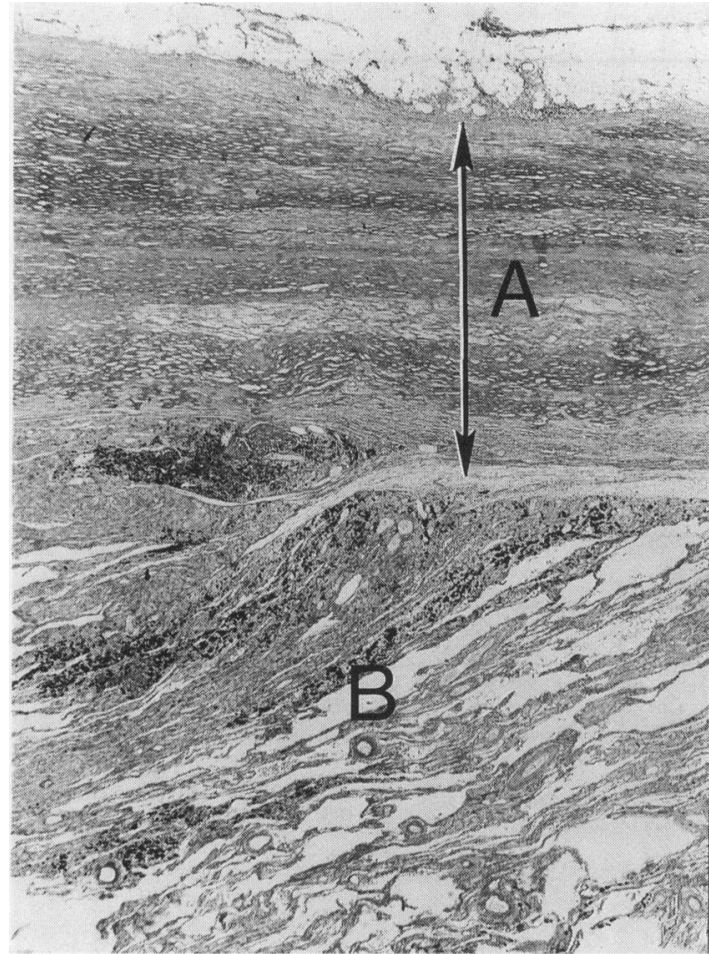

Fig 2 Histological sections from case 2, showing a basket weave pattern of the thickened collagenous pleura $(A)$ with underlying interstitial fibrosis of the lung $(B)$.

(Haematoxylin and eosin, $\times 14$.)

lungs from the thoracic cavity at necropsy. In several places, however, the visceral pleura although thickened was smooth with no adhesion to the chest wall. In four cases discrete typical parietal pleural plaques were identified in addition to diffuse pleural fibrosis. No effusions, empyema, or tumour were seen in the pleural space at necropsy. Macroscopic assessment of lung parenchymal fibrosis was made difficult by the presence of lung cancer in three cases and severe pneumonia in three cases.

\section{Microscopic findings}

All the cases showed similar histological features. The most striking feature was the basket weave pattern of fibrosis, with preservation of the external elastic laminae and submesothelial fat in many areas of diffuse fibrosis (figs 2 and 3). In other areas there was adhesion of the visceral and parietal layers with obliteration of the pleural space, elastic laminae, and submesothelial fat. Little fibrinous exudate was seen on the pleural surface and no cellular fibroblastic proliferation or organisation was present. In addition, no mesothelial hyperplasia (or neoplasia) was identified.

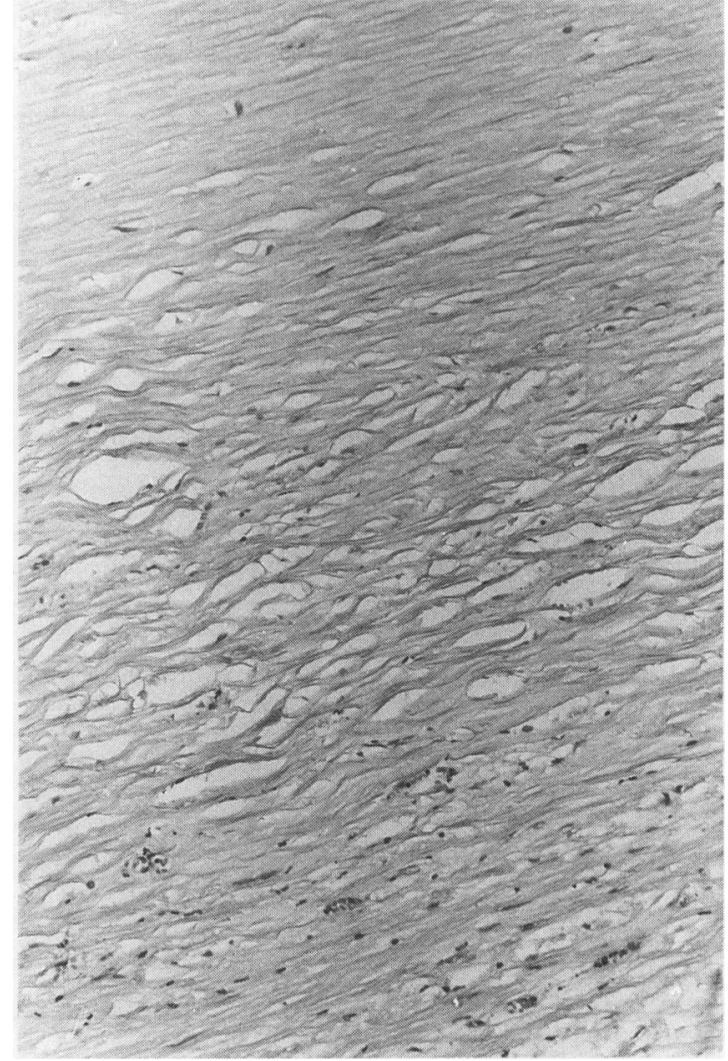

Fig 3 Histological section from case 2 at higher magnification, showing the basket weave pattern of the pleural fibrosis. (Haematoxylin and eosin, $\times 117$.)

In all cases there was dense subpleural parenchymal interstitial fibrosis and fine honeycombing, but this did not extend more than $1 \mathrm{~cm}$ into the underlying lung (fig 2). The degree of pulmonary interstitial fibrosis ranged from 1 to 3 (table 2). There was extensive pleural calcification in case 4 , but in the others it was inconspicuous.

\section{MINERA LOG Y}

Table 3 shows the asbestos fibre counts by light and electron microscopy. The amphibole (crocidolite and amosite) counts in six cases were high, ranging from 2.4 to $28 \times 10^{6} / \mathrm{g}$ dried lung. In case 6 , however, the amphibole count was relatively low and within our normal range (less than $10^{6} / \mathrm{g}$ dried lung).

\section{Discussion}

Diffuse pleural fibrosis was considered to be an unusual manifestation of asbestos exposure, but 
Table 2 Diffuse pleural fibrosis: cause of death and pathological features

\begin{tabular}{|c|c|c|c|}
\hline Case No & (Agey) & Cause of death & Pathological features \\
\hline 1 & 80 & $\begin{array}{ll}1 a & \text { Cor pulmonale } \\
1 b & \text { Diffuse pleural fibrosis } \\
1 c & \text { Asbestosis }\end{array}$ & Grade 2 interstitial fibrosis \\
\hline 2 & 75 & $\begin{array}{l}\text { la Bronchopneumonia } \\
1 b \text { Diffuse pleural fibrosis } \\
1 c \text { Asbestosis }\end{array}$ & interstitial fibrosis \\
\hline $\begin{array}{l}3 \\
4\end{array}$ & $\begin{array}{l}67 \\
69\end{array}$ & $\begin{array}{l}\text { 1a Myocardial infarction } \\
\text { la Carcinomatosis } \\
\text { lb Carcinoma of lung }\end{array}$ & $\begin{array}{l}\text { Grade 2-3 interstitial fibrosis } \\
\text { Grade 2-3 interstitial fibrosis } \\
\text { Adenocarcinoma }\end{array}$ \\
\hline 5 & 58 & $\begin{array}{l}\text { 1a Carcinomatosis } \\
1 b \text { Carcinoma of lung } \\
2 \text { Asbestosis }\end{array}$ & $\begin{array}{l}\text { Grade } 1 \text { interstitial fibrosis } \\
\text { Adenocarcinoma }\end{array}$ \\
\hline 6 & 68 & $\begin{array}{l}1 a \text { Senile myocardial degeneration } \\
2 \text { Pleural fibrosis }\end{array}$ & Grade 1 interstitial fibrosis \\
\hline 7 & 64 & $\begin{array}{l}1 a \text { Pneumonia } \\
2 \text { Carcinoma of lung }\end{array}$ & $\begin{array}{l}\text { Grade } 1-2 \text { interstitial fibrosis } \\
\text { Large cell carcinoma }\end{array}$ \\
\hline
\end{tabular}

Table 3 Mineral fibre analysis in seven cases of diffuse pleural fibrosis

\begin{tabular}{|c|c|c|c|c|c|c|c|c|}
\hline \multirow[b]{2}{*}{$\begin{array}{l}\text { Case } \\
\text { No }\end{array}$} & \multirow{2}{*}{$\begin{array}{l}\text { LM counts } \\
\text { per } g \\
\text { dried lung }\end{array}$} & \multicolumn{7}{|c|}{ EM counts $\left(10^{6}\right.$ per $g$ dried lung $)$} \\
\hline & & $\begin{array}{l}\text { Total } \\
\text { fibre count }\end{array}$ & Crocidolite & Amosite & Chrysotile & Mullite & Rutile & Other \\
\hline $\begin{array}{l}1 \\
2 \\
3\end{array}$ & $\begin{array}{l}100000 \\
131027 \\
\text { Not done }\end{array}$ & $\begin{array}{r}24 \cdot 4 \\
83 \cdot 5 \\
9 \cdot 2\end{array}$ & $\begin{array}{r}0.5 \\
10.7 \\
1.8\end{array}$ & $\begin{array}{l}8.3 \\
2.9 \\
0.7\end{array}$ & $\begin{array}{l}2.5 \\
8.8 \\
1.6\end{array}$ & $\begin{array}{r}12 \cdot 6 \\
60 \cdot 1 \\
4 \cdot 4\end{array}$ & $\begin{array}{l}\overline{1 \cdot 0} \\
0.3\end{array}$ & \multirow{4}{*}{$\begin{array}{l}\text { Talc } 0.5 \\
\text { Iron particles } \\
\text { Muscovite } 0.2 \\
\text { Talc } 0.2 \\
\text { Actinolite } 1.75 \\
\text { Iron oxide } 11.5 \\
-\quad \\
\text { Silica } 0.5 \\
\text { Aluminium } 0.5\end{array}$} \\
\hline 4 & 306000 & $48 \cdot 2$ & $5 \cdot 8$ & 0.9 & $6 \cdot 7$ & $21 \cdot 5$ & - & \\
\hline $\begin{array}{l}5 \\
6\end{array}$ & $\begin{array}{l}378000 \\
\text { Not done }\end{array}$ & $\begin{array}{l}39 \\
28.9\end{array}$ & $\begin{array}{l}28.08 \\
-\end{array}$ & $\overline{0.5}$ & $\begin{array}{r}8.9 \\
14 \cdot 4\end{array}$ & $\overline{9} .6$ & $\begin{array}{l}1.95 \\
3.4\end{array}$ & \\
\hline 7 & 29130 & $12 \cdot 5$ & $1 \cdot 4$ & 1.4 & $3 \cdot 5$ & $6 \cdot 1$ & 0.1 & \\
\hline
\end{tabular}

increasing awareness of this association is reflected in clinical reports of incidence varying from $6 \%$ to $36 \% .{ }^{8-10}$ All of the cases fulfilled the criteria of compensatable disease - namely, bilateral, over $5 \mathrm{~mm}$ thick, and covering more than one quarter of the chest wall. ${ }^{2}$ These diagnostic recommendations are preliminary and clarification of the clinical, radiological, and pathological features will be necessary to understand and define the limits of this condition more carefully.

The pathological changes of diffuse pleural fibrosis were described initially by Gloyne ${ }^{11}$ and subsequently by Wagner, ${ }^{2}$ but have received scant attention since. There are both similarities and differences between diffuse pleural fibrosis and pleural plaques. The present cases show extensive continuous fibrosis, affecting mainly the visceral pleura; by contrast, plaques tend to be discrete localised lesions confined to the parietal pleura. Another difference is that adhesions between the visceral and parietal pleura are common with diffuse pleural fibrosis but unusual with plaques. Cases of extensive plaque formation are well described but these tend to be discontinuous lesions clearly identified as plaques. A small proportion of plaques, however, have visceral extension and adhesion and can coexist with diffuse pleural fibrosis.
These borderline lesions suggest that there may be 롱 continuum between plaque and diffuse pleurat fibrosis. Microscopically there are several similarities including the typical basket weave fibrous structuren focal lymphocytic collections, and scant cellulab fibroblastic activity. In diffuse pleural fibrosis, how ever, there is fusion of the two pleural layers witis obliteration of the submesothelial elastic tissue and much of the fatty connective tissue, suggesting that severe inflammatory reaction has occurred. A notable feature in all these cases of diffuse pleural fibrosis is 2 thin subpleural honeycombing (interstitial fibrosis without appreciable diffuse parenchymal disease This change may be explained by pleural drift of the mineral fibres. ${ }^{12}$ In none of these cases was evidence् of asbestosis detected clinically or radiologically. The degree of pleural fibrosis appeared disproportionate to the parenchymal fibrosis.

The cases presented here are clearly related te̊ occupational exposure to asbestos. It is also apparento that they are associated with both a higher tota asbestos count than non-occupationally exposed indiळ viduals and a different fibre distribution. In our labos ratory non-exposed individuals have light micro $\overline{0}$ scopic counts below 20000/g dried lung and cases with pleural plaques $10000-50000 / \mathrm{g}$ dried lung ${ }^{13}$ 
these cases of diffuse pleural fibrosis clearly exceed this and reach the numbers observed in minimal to slight asbestosis. This is paralleled by the high total electron microscopic counts. Not only are the total electron microscopic counts raised but the numbers of amphiboles are high. In non-occupationally exposed individuals amphiboles were all under $2 \times 10^{6} / \mathrm{g}$ dried lung, ${ }^{13}$ whereas in six out of seven cases of diffuse pleural fibrosis the values are considerably higher. Churg ${ }^{14}$ has also found high levels of amphibole in lungs with pleural plaques.

Four of the cases moreover had high mullite counts; we do not at present know whether this is important. In view of the differences in fibre counts between cases of diffuse pleural fibrosis, plaques, and interstitial fibrosis, investigation of the physical characteristics of the fibres, such as aspect ratio, are required to shed further light on the pathogenesis of the different reactions.

Several conditions can give rise to diffuse pleural fibrosis with obliteration of the pleural space, including trauma, tuberculosis, pleurisy, emphysema, and rheumatoid arthritis. ${ }^{15}$ In the present series there was no evidence of any of these conditions. Diffuse pleural fibrosis has long been recognised as a component of severe interstitial fibrosis induced by heavy asbestos exposure, ${ }^{13}$ and more recently as a consequence of asbestos exposure without appreciable pulmonary fibrosis. ${ }^{2}$ Several authors have noticed that diffuse pleural fibrosis can develop within a few months, ${ }^{16}$ and that it may be a sequel to benign recurrent pleural effusion associated with asbestos. ${ }^{1215}$ One third of the cases of McLoud et al ${ }^{10}$ were associated with previous effusions. In the present series only two out of seven had a history of such effusions, but silent episodes could have occurred in the other cases. The fibrosis is considered by some to result from direct inflammatory damage to the mesothelium with subsequent effusion and healing. ${ }^{15}$ The presence of adhesions and obliteration of the external elastic laminae supports this contention but it does not shed any light on whether it is due to recurrent acute episodes or chronic progressive change. The similarity of the histological appearances of diffuse pleural fibrosis and of plaques raises the possibility that the fibrosis is not simply an organised inflammatory exudate but may have a pathogenesis similar to that of plaque formation. The exact mechanism of this is obscure but, in contrast to the pleurisy, direct mesothelial damage is considered not to occur. ${ }^{1517}$ The subpleural fibrosis noted in these cases indicates that local parenchymal damage had occurred, which may be explained by the pleural drift of fibres. The substantial pleural reaction may be related to the physical nature of the mineral fibres, but individual susceptibility cannot be excluded. Immunological abnormalities have been described in individuals exposed to asbestos. ${ }^{18-20}$ Hillerdal $^{20}$ found that patients with a persistently raised erythrocyte sedimentation rate had radiological evidence of pleurisy or its sequelae, whereas the rate was normal in patients with plaques. He concluded that immunological factors played a part in the pathogenesis of the pleurisy.

In conclusion, diffuse pleural fibrosis is a specific asbestos associated entity. The mineral fibre counts fall between the counts found with plaque formation and with minimal asbestosis. The pathogenesis is uncertain and further work on immunological function and the physical characteristics of the mineral fibres present is required to explain the evolution of this particular reaction.

\section{References}

1 Wagner JC. Some pathological aspects of asbestosis in the Union of South Africa. In: Orenstein AJ, ed. Proceedings of pneumoconiosis conference. London: Churchill, 1959:373-82.

2 Davis D. Asbestos related diseases without asbestosis. Br Med J 1983;287:164.

3 Hinson KFW, Otto H, Webster I, Rossiter CE. Criteria for the diagnosis and grading of asbestosis. In: Bogovski P, ed. Biological effects of asbestos. Lyons: World Health Organisation, 1973:54-7.

4 Craighead JE, Abraham JL, Churg A, et al. Asbestos associated disease. Report of the pneumoconiosis committee of the College of American Pathologists and National Insitute for Occupational Safety and Health. Arch Pathol Lab Med 1982;106:541-95.

5 Ashcroft T, Heppleston AG. The optical and electron microscopic determination of pulmonary asbestos fibre concentration and its relation to the human pathological reaction. J Clin Pathol 1973;23:224-34.

6 Wagner JC, Pooley FD, Berry G, et al. A pathological and mineralogical study of asbestos related deaths in the United Kingdom in 1977. Ann Occup Hyg 1982;26:423-30.

7 Pooley FD, Clarke NJ. Quantitative assessment of inorganic fibrous particles in dust samples with an analytical transmission electron microscope. Ann Occup Hyg 1979;22:253-71.

8 McLoud TC, Wood BO, Carrington CB, Epler GR, Gaensler EA. Diffuse pleural thickening in an asbestos exposed population. AJR 1985;144:9-18.

9 Albelda SM, Epstein DM, Gefter WB, Miller WT. Pleural thickening: its significance and relationship to asbestos exposure. Am Rev Respir Dis 1982;126:621-4.

10 Gaensler EA, Kaplan AI. Asbestos pleural effusion. Ann Intern Med 1971;74:178-91.

11 Gloyne SR. The morbid anatomy and histology of asbestosis. Tubercle 1933;14:445-51,493-7.

12 Gibbs AR, Seal RME, Wagner JC. Pathological reactions of the lung to dust. In: Morgan WKC, Seaton A, eds. Occupational lung diseases. 2nd ed. Philadelphia: Saunders, 1984:129-62.

13 Jones JSP, Pooley FD, Clarke NJ, et al. The pathology 
and mineral content of lungs in cases of mesothelioma in the United Kingdom in 1976. In: Wagner JC, ed. Biological effects of mineral fibres. Lyons: International Agency for Research on Cancer, 1980:79-87.

14 Churg A. Fibre counting and analysis in the diagnosis of asbestos related disease. Hum Pathol 1982;13:381-92.

15 Herbert A. Pathogenesis of pleurisy, pleural fibrosis and mesothelial proliferation. Thorax 1986;41:176-89.

16 Wright PH, Hanson A, Kreel L, Capel LH. Respiratory function after asbestos pleurisy. Thorax 1980;35:31-6.

17 Thompson JG. The pathogenesis of pleural plaques. In: Shapirn HA, ed. Pneumoconiosis. Proceedings of inter- national conference. Johannesburg 1969. Cape Town Oxford University Press, 1969:138-41.

18 Lange A. An epidemiological survey of immunologic abnormalities in asbestos workers: I. Nonorgan an organ specific autoantibodies. Environ Res 1980;22:162-75.

19 Lange A. An epidemiological survey of immunologicâ abnormalities in asbestos workers: II. Serum immu $\rho$ noglobulin levels. Environ Res 1980;22:176-83.

20 Hillerdal G. Pleural changes and exposure to fibrous minerals. Scand J Environ Health 1984;10:473-9. 